\title{
Gender, handedness, speed, and visuoconstructive performance in public junior high school students: a neurobehavioural approach
}

Lily D. Sidiarto

\begin{abstract}
Abstrak
Penelitian sebelumnya mengenai kemampuan visual-konstruksi dengan Tes Konstruksi Balok Tiga-Dimensi di Jakarta dilakukan pada pasien dengan stroke dan cedera kepala yang dikaitkan dengan letak lesi di otak, tetapi tes ini belum pernah dilakukan pada orang normal. Penelitian ini bertujuan untuk melihat perbedaan fungsi visual-konstruksi antara laki-laki dan wanita, dan antara cekat tangan kanan dan bukan cekat tangan kanan. Selain itu, mengukur kecepatan kerja yang dikaitkan dengan fungsi hemisfer kanan dan kiri. Hasil Tes Konstruksi Balok Tiga-Dimensi pada 166 anak-anak Sekolah Lanjutan Tingkat Pertama Negeri, dengan rentang usia $12-16$ tahun menunjukkan bahwa tidak ada perbedaan bermakna pada nilai penampilan dan kecepatan antara anak laki-laki dan wanita, dan antara cekat tangan kanan dan bukan cekat tangan kanan. Walaupun anak laki-laki dapat menyelesaikan tes tersebut lebih cepat daripada wanita, secara statistik perbedaannya tidak bermakna. Nampaknya pada rentang usia tersebut terjadi organisasi bilateral sehingga tidak terdapat perbedaan skor visual-konstruksi. Namun demikian, untuk membuktikan hal ini diperlukan penelitian lebih lanjut dengan sampel yang lebih besar dan metodologi yang sama.
\end{abstract}

\begin{abstract}
Previous studies on visuoconstructional performance using Three-Dimensional Block Construction Test in Jakarta were performed in patients with stroke and brain injury, but not yet carried out in normal subjects. This study analyzed the individual differences in visuoconstructive performance level, between boys and girls, and between right-handers and non-right-handers. Furthermore, the speed associated with the right and left hemisphere functions was analyzed. The result of the test using the Three-Dimensional Block Construction Test in 166 students of the public yunior high school with an age range of 12-16 years showed no significant differences in visuoconstructive performance and speed between boys and girls, and between right-handers and non-right-handers. The time required to finish the tasks was shorter in boys than girls, although statistically it was not significant. It seems that at the age range bilateral brain organization exists so that the two sexes present no difference in their visuoconstructive performance. However, before a conclusion can be reached, further studies should be conducted in larger scale using the same methodology.
\end{abstract}

Keywords: visuoconstructive function, sex, hand and eye preference, sinistrality and time, cerebral dominance.

Behavioral neurology is a rapidly evolving discipline in which clinicians and researchers are engaged to explain the nature of brain-behavior relationship in adults and children. In Indonesia behavioral neurology has just started in the 1980's. Studies on behavioral neurology, especially on higher cerebral functions are very rare.

Constructional praxis is one aspect of the higher cerebral functions and held a special interest for neurologists and psychologists. The reason for this is the issue of the distinctive functions of the right hemisphere. Until the 1930s the right hemisphere was often

Department of Neurology, Faculty of Medicine, University of Indonesia, Jakarta, Indonesia termed as "nondominant", "minor", or "silent" hemisphere. Benton pointed out that "an understanding of the determinants and correlates of constructional apraxia is closely related to, and perhaps a prerequisite for an understanding of hemispheric cerebral dominance in man". 1

Cerebral dominance is the superior capacity of each side of the brain to acquire particular skill. In mostinstances cerebral dominance is based on asymmetries of brain structures. It is the result of lateralization which lead to an asymmetrical nervous system. Factors affecting patterns of asymmetry or cerebral dominance are not strictly determined genetically. Fetal factors such as the prenatal testosteron level may have influence on hemispheric development. Geschwind and Galaburda observed that handedness reflects some 
aspect of brain organization. ${ }^{2}$ Left-handedness is usually found to be more common in men than women. Men have generally been found to perform better than women on assessment of spatial orientation and rotation, whereas women are on the average more superior on verbal tests than men. Concerning cerebral functioning of the left and right hemispheres, gender differences in the proficient use of these skills may be related to sexually dimorphic brain organization.

In visuoconstructive performance, copying constructional design is a complex task as it requires manual dexterity, visual perception and motor ability. First the child requires visual perception recognition, then cognitive perception followed by execution of sequential motor acts (ideational praxis). Dexterity differences depend on the extent of complexity and the required precision of the task. The right hemisphere dominates performance concerning spatial tasks, but in performing tasks concerning speed, precision, and ideomotor planning, the left hemisphere plays a dominant role. 3,4 Thus, visuoconstructive processing is not exclusively a right hemisphere function, but the left hemisphere also plays a role.

Zaidel noted that the cognitive-styles of the two hemispheres or "hemispheric typing" of an individual could become useful in personal carreer selection. Furthermore applications of hemispheric specialization theory might promise to educational benefits and research. ${ }^{5}$ Springer and Deutsch suggested that the extent of ability in men and women could be used as major criterion for determining career options and educational opportunities. ${ }^{6}$ This exciting theory of cerebral lateralization becomes increasingly important for developmental studies involving genetics, linguistics, psychology and education.

In Jakarta two studies on three-dimensional constructional praxis were performed in brain damaged patients in association with locus of lesion (in 1991 with stroke patients and in 1994 with brain-injured patients), but was not yet performed in normal subjects.

The aim of this study is to determine whether there are differences in visuoconstructive performance and speed between boys and girls, and between right handers and non-right-handers.

\section{METHODS}

This study was performed in October 1996. The subjects for this study were students of a public junior high school (SLTPN) in Jakarta. The children represented a random selection. They showed no evidence or history of cerebral disease or injury, and no gross neurological signs were found. In this study students of the junior high school were chosen with the assumption that by the age of 12 years and upward no change of handedness occurred and they have already learned the strategies to complete various complex tasks.

To obtain the data concerning manual dexterity or handedness, the child was asked about his/her hand preference (right, left, or both hands) in doing complex manipulative skills (such as writing). I also observed the child in clapping hands; if the upper hand was consistently the right hand, then it might be concluded the presence of right hand dominance. The opposite result meant left hand dominance; and if both hands were used then the result was ambidextral. ${ }^{7,8}$

To determine the dominant eye, the child was told to hold a pencil at arm's length and to direct it up to a point on thewall three meters away, with both eyes open; if the pencil appeared to shift sharply to the right when he closed his right eye, but remained in line when he closed his left eye, then it might be concluded the presence of right eye dominance. The opposite result meant left eye dominance. 9

Familial sinistrality was considered as positive when there was one or more left-handers in one degree relatives.

In this study I classified the children in two main groups (a modification of Subirama's classification): ${ }^{10}$

(1) Group R: the right-handers in whom there were no left lateral tendencies such as left eyedness or history of familial sinistrality.

(2) Group non-R: the non-right-handers in whom there were both hand preference (ambidextrality) or right hand dominance and left eye dominance, or right hand dominance and history of familial sinistrality, or left hand dominance and right eye dominance. Pure left dominance was included in this group.

For the assessment of visuoconstructional praxis, the Three-Dimensional Block models of varying degrees of complexity were used. ${ }^{11-14}$ This model consists of a block set and 3 forms depicting 3 models. The block set contained 29 blocks of various sizes and shapes. The three models were as follows:

Model I. A pyramid made from six $2.5 \mathrm{~cm}$ cubes. Model II. An eight block, four level construction. Model III. A fifteen block, four level construction. 
The children had to copy the presented Three-Dimensional Block model on a tray containing the various blocks. Each time only one model to be copied was presented and the other models remained hidden from the child's view. For each model, the type of errors, such as ommissions, additions, substitutions, displacements were recorded. Rotation of the whole construction or minor rotation of individual block were not counted as errors, but were recorded. The score of the visuoconstructive performance was determined by counting the number of correctly placed blocks (totally there were 29 blocks), so the highest possible score for the three block-models was 29 . The performance score was divided into 2 groups; Group I: for performance score of 29-25 (perfect to near-perfect performance); Group II: for performance score of below 25 (low performance).

The speed or time taken for the completion of each of the three construction models were recorded in seconds. The maximum time allowed for each model was 5 minutes.

\section{RESULTS}

There were 169 students enrolled at the public junior high school (SMPN); three subjects were excluded because of incomplete data. The children included in this study were 166 children consisted of 77 boys and 89 girls. All the subjects were in the age range of 12-16 years with a mean age of 13.6 years $(S D=0.79)$ (figure 1). The mean age of boys was 13.7 years $(S D=0.84)$ and the mean age of girls was 13.6 years $(S D=0.75)$. There was no significant difference in age between boys and girls $(\mathrm{p}=0.73)$.

The overall mean performance score of both sexes was $27.31(\mathrm{SD}=2.28)$. The mean performance score of boys was $27.23(\mathrm{SD}=2.13)$ and girls $27.38(\mathrm{SD}=$ 2.41). No statistically significant difference was found between the two sexes $(p=0.68)$.

Table 1 shows that $150(90.4 \%)$ of the 166 sujects made perfect or near perfect performances (score 29 to 25, Group I) and 16 (9.6\%) made more than 4 errors (score below 25, Group II). In Group I there were 70 boys and 80 girls, while in Group II there were 7 boys and 9 girls. Although girls outnumbered boys in visuoconstructive tasks, the difference was not statistically significant $(\mathrm{p}=0.82)$.

Table 2 shows that there were totally $111(66.9 \%)$ right-handers (RH) and $55(33.1 \%)$ non-right-handers (NRH). In boys there were $52(67.5 \%) \mathrm{RH}$ and 25
(32.5\%) NRH, while in girls there were $59(66.3 \%) \mathrm{RH}$ and $30(33.7 \%) \mathrm{NRH}$. The overall mean performance score of RH in boys and girls was $27.35(\mathrm{SD}=2.35)$ and mean score of NRH in both sexes was 27.24 (SD= 2.13). There was no significant difference between handedness and performance score $(\mathrm{p}=0.76)$.

Table 1. Block Model Presentation: Distribution of scores in boys and girls

\begin{tabular}{cccc}
\hline $\begin{array}{l}\text { Number of } \\
\text { correct scores }\end{array}$ & $\begin{array}{c}\text { Boys } \\
(\mathrm{n}=77)\end{array}$ & $\begin{array}{c}\text { Girls } \\
(\mathrm{n}=89)\end{array}$ & $\begin{array}{c}\text { All subjects } \\
(\mathrm{n}=166)\end{array}$ \\
\hline 29 & 32 & 47 & 79 \\
28 & 12 & 9 & 21 \\
27 & 9 & 10 & 19 \\
26 & 9 & 4 & 13 \\
25 & 8 & 10 & 18 \\
24 & 1 & 3 & 4 \\
23 & 3 & 3 & 6 \\
22 & 1 & 0 & 1 \\
21 & 1 & 1 & 2 \\
20 & 1 & 1 & 2 \\
16 & 0 & 1 & 1 \\
\hline
\end{tabular}

Table 2. Distribution of handedness in boys and girls, and the overall visuoconstructive performance score

\begin{tabular}{cccccccc}
\hline Handed- & \multicolumn{2}{c}{ Boys } & \multicolumn{2}{c}{ Girls } & \multicolumn{2}{c}{ Total } & \multicolumn{2}{l}{ Score } \\
ness & $\mathrm{n}$ & $\%$ & $\mathrm{n}$ & $\%$ & \multicolumn{1}{c}{$\mathrm{n}$} & $\%$ & Mean \\
\hline RH* $^{*}$ & 52 & 67.5 & 59 & 66.3 & 111 & 66.9 & 27.35 \\
NRH $^{* *}$ & 25 & 32.5 & 30 & 33.7 & 55 & 33.1 & 27.24 \\
\hline Total & 77 & 100.0 & 89 & 100.0 & 166 & 100.0 & 27.31 \\
\hline
\end{tabular}

$\mathrm{p}>0.05$

* $\mathrm{RH}=$ right-handers

** NRH= non-right-handers

Table 3 shows that in the right handed boys $47(90.4 \%)$ were in group I and $5(9.6 \%)$ were in group II. In the non right handed boys $23(92.0 \%)$ were in group I, while only $2(8.0 \%)$ were in group II. The mean performance score in $\mathrm{RH}$ was $27.27(\mathrm{SD}=2.22)$ and in $\mathrm{NRH}$ it was $27.16(\mathrm{SD}=1.97)$. There was no significant difference in visuoconstructive performance between right handers and non right handers $(\mathrm{p}=0.82)$.

In the right handed girls, $53(89.8 \%)$ were in group I and $6(10.2 \%)$ were in group II; in the non right handed girls $27(90.0 \%)$ were in group I, while $3(10.0 \%)$ were in group II. The mean performance score in $\mathrm{RH}$ was $27.42(\mathrm{SD}=2.48)$ and in $\mathrm{NRH}$ it was $27.30(\mathrm{SD}=2.29)$. No significant difference was found in visuoconstructive performance between right handers and non right handers $(p=0.98)$. 


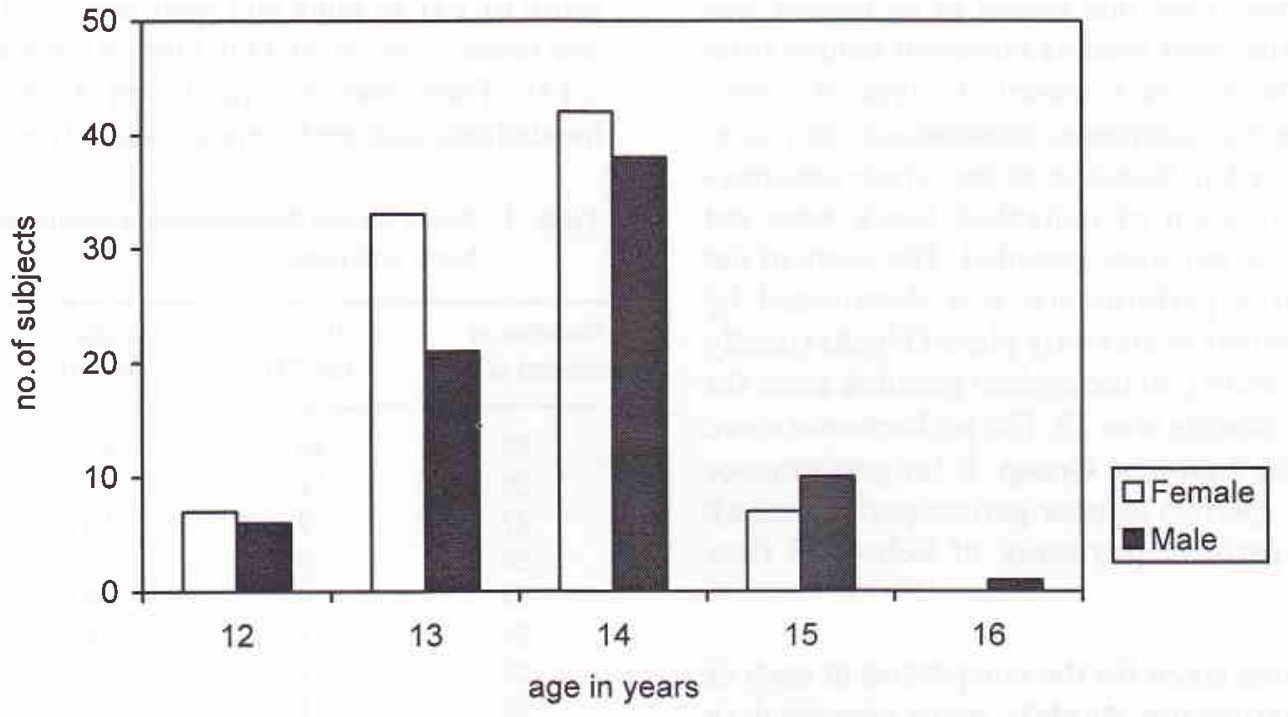

Figure 1. Distribution of age in boys and girls

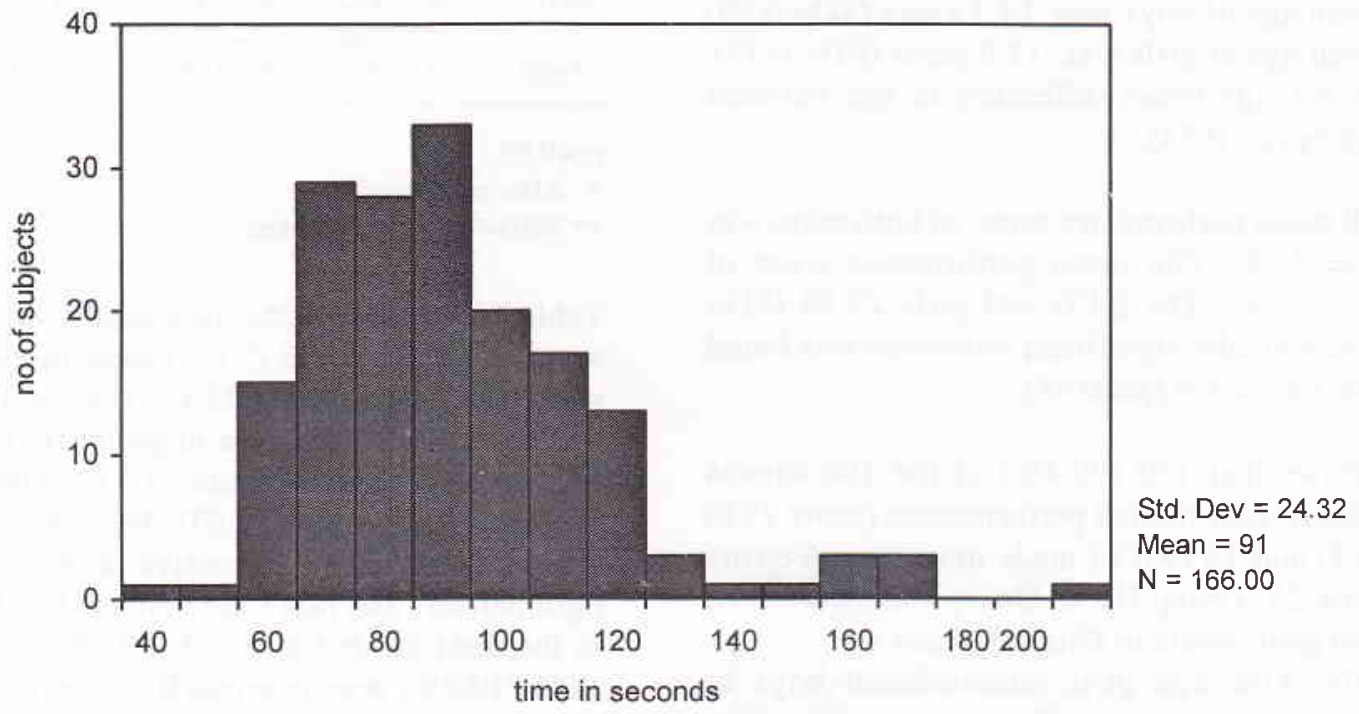

Figure 2. Distribution of time taken for the completion of visuoconstructive performance 
Table 3. Relationship between handedness and visuoconstructive performance in boys and girls

\begin{tabular}{|c|c|c|c|c|c|c|}
\hline \multirow[b]{2}{*}{ Score } & \multicolumn{2}{|c|}{ Boys } & \multicolumn{4}{|c|}{ Girls } \\
\hline & $\begin{array}{c}\mathrm{RH} \\
\mathrm{n} \\
(\%)\end{array}$ & $\begin{array}{c}\text { NRH } \\
\text { n } \\
(\%)\end{array}$ & Total & $\begin{array}{c}\mathrm{RH} \\
\mathrm{n} \\
(\%)\end{array}$ & $\begin{array}{c}\text { NRH } \\
\mathrm{n} \\
(\%)\end{array}$ & Total \\
\hline Group I & $\begin{array}{c}47 \\
(90.4)\end{array}$ & $\begin{array}{c}23 \\
(92.0)\end{array}$ & $\begin{array}{c}70 \\
(90.9)\end{array}$ & $\begin{array}{c}53 \\
(89.8)\end{array}$ & $\begin{array}{c}27 \\
(90.0)\end{array}$ & $\begin{array}{c}80 \\
(89.9)\end{array}$ \\
\hline Group II & $\begin{array}{c}5 \\
(9.6)\end{array}$ & $\begin{array}{c}2 \\
(8.0)\end{array}$ & $\begin{array}{c}7 \\
(9.1)\end{array}$ & $\begin{array}{c}6 \\
(10.2)\end{array}$ & $\begin{array}{c}3 \\
(10.0)\end{array}$ & $\begin{array}{c}9 \\
(10.1)\end{array}$ \\
\hline Total & $\begin{array}{c}52 \\
(100.0)\end{array}$ & $\begin{array}{c}25 \\
(100,0)\end{array}$ & $\begin{array}{c}77 \\
(100.0)\end{array}$ & $\begin{array}{c}59 \\
(100.0)\end{array}$ & $\begin{array}{c}30 \\
(100.0)\end{array}$ & $\begin{array}{c}89 \\
(100.0)\end{array}$ \\
\hline
\end{tabular}

$\mathrm{p}>0.05$

Group I: performance score of 29-25

Group II: performance score of below 25

RH : right-handers

NRH : non-right-handers

The mean performance score of right handed boys was $27.27(\mathrm{SD}=2.22)$, while right handed girls showed performance score of $27.42(\mathrm{SD}=2.48)$. No significant difference was found between the two sexes ( $\mathrm{p}=0.73$ ). The mean performance score of non right handed boys and girls were $27.16(\mathrm{SD}=1.97)$ and $27.30(\mathrm{SD}=2.29)$ respectively. These findings showed that statistically there was no significant difference between boys and girls.

The result of familial sinistrality showed that 3 of the boys had a brother and/or a mother with left-handedness, and 7 of the girls had familial sinistrality. Only one girl $(0.6 \%)$ showed pure left dominance and one boy $(0.6 \%)$ was left-handed, but showed right eyedness.

Figure 2 shows the distribution of the time taken for the completion of visuoconstructive performance in all subjects. The mean time required to finish the constructional tasks in 77 boys was 87.38 seconds ( $S D=$ 23.81 ), and in 89 girls it was 94.00 seconds ( $\mathrm{SD}=$ 24.47). No significant difference in speed was found between boys and girls $(\mathrm{p}=0.08)$.

In boys: the mean time required to finish the tasks in group I was $87.76(\mathrm{SD}=24.58)$ and in group II it was $83.64(\mathrm{SD}=14.58)$. In girls: the mean time to finish the tasks in group I was $92.55(\mathrm{SD}=23.82)$ and in group II it was $106.89(\mathrm{SD}=27.83)$. The mean time to finish the tasks in both sexes in $\mathrm{RH}$ was $89.84(\mathrm{SD}=23.44)$ and in NRH was $93.13(\mathrm{SD}=28.08)$. Statistically, no significant difference in speed was found between $\mathrm{RH}$ and NRH $(\mathrm{p}=0.88)$.

\section{DISCUSSION}

This study examined individual differences in term of performance and speed, between male and female, and between right-handers and non-right-handers, in specialized cognitive tasks using the Three-Dimensional Constructional model that are associated with the right and left hemispheres.

The results of the visuoconstructive tasks showed that 79 of the 166 students made errorless performance, while 71 students made 1-4 errors and the remaining 16 students made more than 4 errors. The mean age of the subjects was 13.6 years and the education level was 7-8 years. Compared with the results of the control group of Benton's study on the same tasks, 78 of the 100 subjects made perfect performance and 22 made 1-4 errors. The mean age was 42 years and the mean education level was 10 years. ${ }^{12}$ The difference in performance might be due to the difference in education level. Education level can affect performance, as the learned strategies (to copy a complex pattern) play an important role.

\section{Gender differences}

In the present study girls outnumbered boys in visuoconstructive performance but statistically no significant gender difference was found (see Table 1). 
This result did not support the theoretical standpoint that males performed better than females on spatial tasks. Trying to explain this, the author refer to the following evidence. Gordon and Kravetz ${ }^{15}$ reported that many studies did not demonstrate a gender difference or the differences were very small in cognitive functioning. However, he emphasized Birkett's study in 1980, that a male superiority was found on spatial relation subtest of the Differential Aptitude Tests. Gordon and Kravetz ${ }^{15}$ found out that males outperformed females on three-dimensional version of task in the age groups of 15-18 years. This inconsistent results might be due to Deborah Waber's suggestion that verbal and spatial abilities did not relate to sex differences, but might be related to differences in sex- maturational rate. Females in general gain physical maturity at an earlier age than males. She predicted that "early maturers have better verbal than spatial abilities; late maturers perform better on spatial tasks than verbal ones"; and this was confirmed by the results of her study with several standardized tests on verbal and spatial abilities. Springer and Deutsch mentioned Levy's suggestion on the evolutionary basis for sex differences in lateralization. ${ }^{6}$ A study performed by Karapetsas and Vlachos in 1992 showed that left handed girls had better bilateral brain organization than boys and also got better rates in visuomotor organization performance. ${ }^{16}$ They supposed that the small differences in visuomotor performance in the two sexes was due to the myelination process of the cerebral commissures which is completed by 9 years of age as studied by Yakovlev and Lecours, in 1967.,5

\section{Handedness differences}

The traditional culture in Indonesia is using the "good hand", i.e the right hand as the preferred hand for shaking hands, accepting and giving objects to other people, especially to older ones in early childhood. In the kindergarten (at preschool age) when starting to use pencil to draw or write, there is a tendency from parents or teachers to force these children to use their right hands. This might be one of the reason that in this study $66.9 \%$ of the subjects were right-handers $(\mathrm{RH})$ and $33.1 \%$ were non-right-handers (NRH). Among the nonright-handers only one girl $(0.6 \%)$ was pure left-hander and one boy $(0.6 \%)$ was left handed, but right eyed. The remaining subjects were ambidextrous (see Table 2). It is difficult to identify whether these non-right handers were genetic, pathologic or as the result of environmental/ social pressure to shift their preferred hand from left to right, the so called 'shifted non-right handers' or 'handedness switch'. To determine pathologic or genetic non-right handers, a complete history, clinical examination, and neuroimaging should be done. This was not done in this present study.

A study performed by Kusumoputro showed that among the 123 medical undergraduates in Jakarta, the incidence of left handed and ambidextrous students were $0.8 \%$ and $15 \%$ respectively. ${ }^{17}$ Hoosain reported Guo's survey in 1984 on handedness switch due to traditional culture in the People's Republic of China. In this survey of 10314 Chinese there was a low incidence of left-handedness $(0.26 \%)$ and also of ambidextrous people (8.94\%). ${ }^{18}$ These figures were far from the range of $5 \%$ to $10 \%$ incidence of left handedness reported in Western countries. ${ }^{2,4,19}$

Young suggests that fine motor movements are more relevant than gross motor (hand and arm) movements in determining the relationship between hemispheric specialization and contralateral behaviour (cited by Hoosan). ${ }^{20}$ This suggestion might influence the result of the performance of the visuoconstructive praxis in this present study. In this study shifted handedness was not identified, so this might explain that statistically the overall results showed no difference in visuoconstructive tasks between RH and NRH in boys and girls (see Table 3).

The results in this study showed that in visuoconstructive tasks, right handed boys with good result outnumbered non right handed boys ( 47 and 23 respectively). Also the number of right handed girls with good result outnumbered non right handed girls. This results support Levy's notion that non-right-handers scored lower than right-handers on non-verbal visuospatial abilities. The explanation for his findings was that in left-handers "both sides of the brain have developed to a certain degree, according to the verbal blueprint, and this impedes the mediation of visuospatial abilities by the right hemisphere" (cited by Bishop, 1990). ${ }^{21}$

In Group I, right handed girls having good performance slightly outnumbered right handed boys, (53 and 47 respectively). Non right handed girls (27) somewhat outnumbered non right handed boys (23). In the lower performance group (group II) right handed and non right handed girls somewhat outnumbered right handed and non right handed boys (see Table 3). It could be seen that girls made either perfect performance or very low performance (lowest score was 16), while in boys the lowest score was 20 (Table 1). This support Benton's study (on photographic presentation of the Three-Dimensional Block Construction) that there was no difference in the proportion of men and women making 2 or more errors, but women made more variable scores (either perfect score or very poor 
score. ${ }^{12}$ A study by Karapetsas and Vlachos in lefthanded children revealed that girls showed better performance on visuomotor organization than boys. The explanation was that the two sexes had different ways of perceiving the complex figure and this might reflect different lateralization of brain functions. ${ }^{16}$ Bouma mentioned Kimura's statement in 1977 that "males and females probably differ in brain organization for intellectual and problem solving behaviors". 3 Springer and Deutsch concluded that overall girls showed more bilateral representation for both types of functions. ${ }^{6}$

\section{Speed differences}

The mean time needed for the completion of the tasks was shorter in boys than girls, 87.38 and 94.00 seconds respectively, but statistically this was not significant. No difference in speed between the two sexes was also found in right-handers ( $89.84 \mathrm{sec}$.) and non-right handers $(93.13 \mathrm{sec}$.). The mean visuoconstructive time in right handed and non right handed boys was 88.0 and 86.4 seconds respectively, while in right handed and non right handed girls was 92.8 and 98.4 seconds respectively. This results suggest that boys finished the tasks more quickly but made more errors than girls.

This controversial data might be due to the different sample size, the source or different age groups of the subjects, and to the types and extent of visuospatial tasks performed to the subjects.

\section{CONCLUSION}

The present study on visuoconstructive tasks regarding gender, handedness, and speed differences could be resolved as follows:

* $90.4 \%$ of the subjects made perfect or near perfect performance.

* No significant gender difference was found on visouconstructive performance.

* Right-handed boys and girls performed better than non-righthanders, although statistically the difference was not significant.

* No significant difference in performance was found between right handed boys and right handed girls, also between non right handed boys and non right handed girls

* The time required to finish the tasks was shorter in boys than girls.

Having the above results, we could interpret that there was statistically no difference in performance and speed on visuoconstructive tasks between boys and girls and between right handers and non right handers.
It seems that at this age range bilateral organization exists so that the two sexes present small or no difference in their visuoconstructive performance. However, before a conclusion on the application theory of cerebral lateralization can be reached, further studies should be made.

Suggestions: To solve the problem concerning the relation between brain and behaviour, the difficulties in understanding the functional neural system during the assembling of a complex block pattern, the interactions and the role of culture/environmental functions and the gradual maturation of the brain of the child, further research should be done with focus on the interaction of the three parameters of age, sex, and handedness on visuoconstructive abilities on larger scale subjects.

\section{REFERENCES}

1. Benton AL. Constructional apraxia and the minor hemisphere. Conf Neurol 1967;29:1.

2. Geschwind N, Galaburda AM. Cerebral lateralization. Biological mechanisms, associations, and pathology: I. A hypothesis and a program for research. Arch Neurol 1985;42:428-59.

3. Bouma A. Lateral asymmetries and hemispheric specialization. Theoritical models and research. Amsterdam/Lisse: Swet \& Zeitlinger; 1990.

4. Njiokiktjien C. Pediatric behavioural neurology. Amsterdam. Suyi Publicaties; 1988. p.160-77.

5. Zaidel E. Implications. In: Benson DF, Eran Zaidel, eds. The dual brain. Hemispheric specialization in humans. New York: The Guilford Press; 1985. p.307-16.

6. Springer SP, Deutsch G. Split-brain research. In: Springer SP, Deutsch G. Left brain, right brain. Revised Edition. New York: Freeman; 1985. p.25-65.

7. Lezak MD. Visuopratic functions and manual dexterity. In: Lezak MD. Neuropsychological assessment. New York: Oxford University Press; 1981. p.310-43.

8. Lezak MD. Constructional Functions. In: Lezak MD Neuropsychological assessment. 2nd ed. New York: Oxford University Press;1983.p.382-413.

9. Luria AR. Traumatic aphasia. Its syndromes, psychology and treatment. The Hague: Mouton; 1970.

10. Subirana A. The prognosis in aphasia in relation to cerebral dominance and handedness. Brain 1958;81:415.

11. Benton AL, Fogel ML. Three-Dimensional Constructional Praxis. Arch Neurol 1962;7:347-54.

12. Benton AL, Hamsher K de S, Varney NR, Spreen O. Contributions to neuropsychological assessment, A clinical manual. New York: Oxford University Press; 1983.

13. Benton A. Visuoperceptual, visuospatial, and visuoconstructive disorders. In: Heilman KM, Valenstein E, eds. Clinical neuropsychology. 2nd ed. New York: Oxford University Press; 1985. p.151-85. 
14. Benton A, Tranel D. Visuoperception, visuospatial, and visuoconstructive disorders. In: Heilman KM, ValensteinE, eds. Clinical neuropsychology. 3rd ed. New York: Oxford University Press;1993. p.165-213.

15. Gordon HW and Kravetz S. The influence of gender, handedness, and performance level on specialized cognitive functioning. Brain and Cognition 1991;15,37-61.

16. Karapetsas A, Vlachos F. Visuomotor organization in the lefthanded child. A neuropsychological approach. Perceptual and motor skills, 1992;75:699-705.

17. Kusumoputro S. Kidal pada sekelompok mahasiswa. Laporan Pendahuluan. Neurona 1990;8(1):1-3.
18. Hoosain R. Left handedness and handedness switch amongst the Chinese. Cortex 1990;26:451-4.

19. Geschwind N, Galaburda AM. Cerebral lateralization. Biological mechanisms, associations, and pathology: II. A hypothesis and a program for research. Arch Neurol 1985;42:521-52.

20. Hoosain R. Cerebral lateralization of bilingual functions after handedness switch in childhood. J Genetic Psychology 1990;152(2):263-8.

21. Bishop DVM. Handedness and developmental disorders. Clinics in developmental medicine No. 110. Philadelphia: Keith Press, Oxford Blackwell Scientific Publ;1990. 